\title{
Judicial Review of Land Bank Dispositions
}

Present mechanisms intended to control land use in the United States have been sharply criticized. ${ }^{1}$ Traditional regulatory devices have in many ways failed to control development, produce an economic use of resources, or provide adequate facilities for a growing metropolitan population. ${ }^{2}$ A variety of alternative methods of land use control have been proposed. ${ }^{3}$ One such alternative, public land banking, has been noted with considerable interest and approval. ${ }^{4}$ Land banking gives the government more direct control over land use patterns than other schemes; large tracts of land are acquired by the government and later disposed of in parcels according to a plan for regional development. Conflicts over the disposition of banked land are inevitable, and proper resolution of such conflicts is essential to the effectiveness of the system. Courts are the final arbiters of conflicts in many similar situations ${ }^{5}$ and are in a good position to provide effective review of land bank dispositions.

This comment examines judicial review of land bank disposition decisions and suggests judicial techniques to curb the two major problems in disposition-dispositions that are inconsistent with land bank

1 Trme, Oct. 1, 1973, at 94-99; see Model Land Development Code xxi-xxviii (Tent. Draft No. 1, 1968). See also notes 2-3 infra.

2 American Soc'y of Planning Officials, Problems of Zoning and Land-Uise ReguLAtion (National Comm'n on Urban Problems Research Report No. 2, 1968); Comment, Public Land Banking: A New Praxis for Urban Growth, 23 CASE W. Res. L. Rev. 897, 903-06 (1972) [hereinafter cited as Public Land Banking]; Note, Land Use Control in Metropolitan Areas: The Failure of Zoning and a Proposed Alternative, 45 S. CAL. L. REv. 835, 338-50 (1972).

3 The most comprehensive reform proposal has been offered by the American Law Institute. MIODEx Land Development Code (Tent. Draft No. 1, 1968); (Tent. Draft No. 2, 1970); (Tent. Draft No. 3, 1971); (Tent. Draft No. 4, 1972); (Tent. Draft No. 5, 1973) [hereinafter cited as Tent. Draft No. 1, 2, 3, 4, or 5].

While this comment deals with a system of greater public control of land use, some commentators have suggested a more privatized system of land use regulation. See, e.g., B. Siegan, LaNd Use Without Zoning (1972); Davis, Economic Elements in Municipal Zoning Decisions, 39 LAND ECoN. 375 (1963); Ellickson, Alternatives to Zoning: Covenants, Nuisance Rules, and Fines as Land Use Controls, 40 U. CHr. L. Rev. 681 (1973); Note, An Economic Analysis of Land Use Conflicts, 21 StAN. L. Rev. 293 (1969).

4 See text and notes at notes 21-27 infra.

5 See, e.g., Norwalk CORE v. Norwalk Redevelopment Agency, 395 F.2d 920 (2d Cir. 1968) (urban renewal); Hoffman v. City of Stillwater, 461 P.2d 944 (Okla. 1969) (zoning). See generally L. JaFfe, Judiclal Control of Administratrve Action 320-27 (1965). 
goals as defined by statute and dispositions that exclude certain uses or groups from an area in conflict with general state policies. In jurisdictions that have already authorized land banking, ${ }^{6}$ effective judicial review is necessary for achieving the statutory goals and controlling abuse. Where land banking programs are being considered, ${ }^{7}$ the effectiveness of judicial review is an important factor in determining both the desirability of land banking and the form of a land bank system.

\section{Public Land Banking}

\section{A. Background and Current Proposals}

In a public land banking system ${ }^{8}$ a governmental entity, which can be an agency of the state, county, or metropolitan government or an independent public corporation, ${ }^{9}$ is endowed with authority to acquire, hold, develop, and dispose of land. The entity uses this authority to exercise direct control over the development of the region and indirect control over the development of nearby regions. ${ }^{10}$ In the first phase of the process, the land bank predicts in general terms the probable and desirable growth patterns of the region. Next, appropriate tracts of land, usually undeveloped, are acquired by purchase, transfer from other government agencies, or eminent domain. This land is then held in reserve, or "banked," until the development situation is ripe for its release. During the holding period it may be plotted and subdivided, and streets, sewers, and other public improvements may be constructed. Finally, the land is transferred under deeds or leases that contain conditions designed to assure that the land use conforms to the development objectives. ${ }^{11}$

6 ILL. Rev. STAT. ch. 671/2, § 307.12 (1971); Ky. Acts ch. 125 (1972); LA. Rev. Stat. ANN. tit. 33, ch. 21 (Supp. 1973); N.Y. Unconsol. Laws §§ 6251-85 (McKinney Supp. 1973); Oнto Rev. Code ANn. ch. 349 (Page Supp. 1972); P.R. LAws ANn. tit. 23, ch. 24 (1964).

7 For example, land banking is being considered for a proposed massive redevelopment of Chicago's South Loop area. Interview with Robert Merriam, Urban Investment and Development Company, in Chicago, Illinois, Feb. 18, 1974.

8 See Tent. Draft No. 5, supra note 3, at 50. While "land banking" can also refer to advance land assembly by private developers, or by government for specific purposes, the term will be used in this comment as defined in the text.

9 M. Grawson, Suburban Land Conversion in the United States: An Economic and Governmental Process 362-63 (1971); Public Land Banking, supra note 2, at 938-44. Compare P.R. LAws ANN. § 311 (1964) with OHro Rev. Code ANN. $\$ 349.03$ (Page Supp. 1972).

10 The nature of the land bank's direct control of development through purchase and sale of land is obvious. The land bank also achieves indirect control over the development of land not publicly owned. The policies as to time and price of dispositions have a powerful impact on the regional land market. Uses that are limited in the land bank area are drawn to surrounding areas. Conversely, factors that attract uses to banked land make other locations less desirable.

11 Bain, The Organization of Growth, in National Comm. on Urban Growtr Policy, 
Land banking is intended to achieve three general goals. The first is control of urban development patterns. ${ }^{12}$ Control over time, location, and type of development allows the land bank to create an effective sequence and arrangement of uses on a local and regional basis. A second goal, related to the determination of land uses, is assurance of an adequate level of all land uses needed in an area..$^{13}$ For example, the land bank can provide for an adequate supply of low and middle income housing. ${ }^{14}$ Finally, land banking can benefit public finances in two ways: centralized control over timing and installation of public services results in economies of scale, ${ }^{15}$ and governmental ownership and resale permits capture of the appreciation in land value caused by government action in aid of growth. ${ }^{16}$

Land bank enabling legislation and development plans define these goals more precisely and establish priorities among goals. The statute sets forth the policies that the land bank is to pursue, ${ }^{17}$ and the development plan applies the legislative intent to specific areas by establishing policies on land acquisition and disposition, future uses, and timing. ${ }^{18}$

Land banking has been used in some American urban areas, ${ }^{10}$

The New CrTy 135, 140-42 (D. Canty ed. 1969). See also Public Land Banking, supra note 2, at 944, 962-74; Reps, The Future of American Planning: Requiem or Renascence?, 1 LAND-Use Controls No. 2, at 3-8 (1967). The development objectives may of course include open spaces or other public uses.

12 National Comm'n on Urban Problems, Bullding the Amartcan Citr 251 (1968); D. Shoup \& R. MACK, AdVANGe LANd AcQuistition by LocAl Governments 100-02 (1968); Tent. Draft No. 5, supra note 3, at 51; Reps, supra note 11, at 4.

13 Finley, A Fresh Start, in National Comm'n ON URban Growth Policy, supra note 11, at 169; D. Shoup \& R. MACK, supra note 12, at 101-02; Reps, supra note 11, at 4-5.

14 This may be done either directly or indirectly through stabilization of the market in raw land and elimination of the speculative profits that discourage construction of low and middle income housing. See Public Land Banking, supra note 2, at 935-38.

15 D. SHoup \& R. MACK, supra note 12, at 100-01; Tent. Draft No. 5, supra note 3, at 51; Public Land Banking, supra note 2, at 929.

16 National Comm'n on Urban Problems, supra note 12, at 251; D. Shoup \& R. Mack, supra note 12, at 100; Public Land Banking, supra note 2, at 930-31.

17 E.g., ILl. Rev. STAT. ch. 671/2, \$ 303 (1971); LA. Rev. STAT. ANN. § 33:7602 (Supp. 1973); N.Y. UNCoNsol. LAws $§ 6252$ (McKinney Supp. 1973).

18 E.g., LA. REv. StAT. ANN. \$ 38:7603(15) (Supp. 1973). A mature planning process will not involve only a single effort to create a written plan followed by dispositions to implement the plan. Planning and operating functions will be continuous and inseparable, and land uses may not be specifically located until late in the planning process. It is useful, however, to conceptualize two stages, separating the planning function from the disposal function. See generally Montgomery, Improving the Design Process in Urban Renewal, 31 J. Am. Inst. OF PLANners 7 (1965).

10 The most famous American urban public land project is Washington, D.C. Land was taken by the government from owners who wanted to hold it for speculative profit. A public agency held the land, planned the entire city, sold parcels for development according to a master plan, and retained large areas for public uses. Reps, supra note 11, at 9-10. Other cities used land banking from the colonial period through the Civil War. $I d$. In more recent times the New Deal Resettlement Administration attempted a na- 
and its effectiveness has been demonstrated in foreign nations. ${ }^{20}$ Reform proposals based on land banking have become more urgent and widespread as the problems caused by inadequate regulation of land use have become more acute. The intense debate of the 1930s and 1940s over public ownership and control of land ${ }^{21}$ has been revived with considerable intensity. Commentators and commissions have urged that governments employ public acquisition and disposition of land to control and channel urban development. ${ }^{22}$ Citizen groups have presented proposals for public land banks in individual cities and states. ${ }^{23}$ Several state legislatures have responded with enabling legislation for land reserve agencies. ${ }^{24}$ Congress, in the Urban Growth and New Community Development Act of $1970,{ }^{25}$ sought to remove financial barriers that had prevented many areas from adopting land banking. Potentially the most influential proposal is presented in the Model Land Development Code of the American Law Institute. ${ }^{26}$ The Reporters' Draft includes, as part of a comprehensive scheme for reform of government

tional program to create greenbelt cities with some success. D. Skoup \& R. MAck, supra note 12, at 103. Puerto Rico presently has the most extensive American land reserve policy. Public Land Banking, supra note 2, at 916-23.

20 Stockholm, for example, has used land banking throughout this century to create a pattern of new towns in the metropolitan area. Today 36 percent of the land in Stockholm and 83 percent of the surrounding land is publicly held. G. EDWARDS, LAND, PEOpLe AND Policy 58 (1969). Other European nations and Canada are engaged in massive land banking programs. Id. at 47-76; $\mathrm{K}$. Parsons \& $\mathrm{H}$. BudKe, Ganadian LAND BaNKS (ASPO Planning Advisory Service No. 284, 1972); Public Land Banking, supra note 2, at 908-12.

21 This debate is reviewed in Tent. Draft No. 5, supra note 3, at 51. See also Comment, Public Land Ownership, 52 Yar. L.J. 634 (1943).

22 Advisory Comm'n on Intergovernmental Relations, Urban and RuRal america: Policies for Future Growth 161 (1968); M. Clawson, supra note 9, at 355-56; National Comm'n on Urban Problems, supra note 12, at 251; National Comm. on Urban Growth Policy, supra note 11, at 172-74; Haar, Wanted: Two Federal Levers for Urban Land Use-Land Banks and Urbank, in PApers Submitted to the Subcomm. on Housing PANels, House Banking and Currency Comm. 92d Cong., 1st Sess. 927 (1971); Reps, supra note 11, at 2-3, and sources cited in Appendix.

23 American Sog'y of Planning Offictals, New Directions in Connecticut Planning Legislation (1967); Baltimore Regional Planning Councir, A Plan for the Metropolitan BaLtmore Regron (1970).

24 See note 6 supra.

2542 U.S.C. \$§ 4501-32 (1970). Under the Act, any public agency with authority to develop new community projects may receive 100 percent of the value of real property acquired and the costs of development in federal loans, up to a maximum of $\$ 50$ million per project. Some state statutes are specifically designed to take advantage of federal funds. E.g., OHo Rev. Code ANN. \$ 349.03 C (Page Supp. 1973).

26 Modez Land Developmenr Code art. 6 (Unpublished Reporters' Draft, 1973) [hereinafter cited as Reporters' Draft.] The Proposed Final Draft of the Code is now in preparation. The Reporters' Draft represents the unofficial and tentative thoughts of the Reporters and was provided through the courtesy of Professor Allison Dunham, the Code's Chief Reporter. Citations to the Reporters' Draft should not be attributed to the American Law Institute. 
regulation of land development, a model article for the establishment of state land reserve agencies that are authorized to engage in the full range of land bank activities. ${ }^{27}$

\section{B. The Need for Judicial Review of Land Bank Dispositions}

Disposition is the stage at which planning is most crucial, where land bank goals are either achieved or thwarted. ${ }^{28}$ Disposition requires a number of complex determinations: ${ }^{29}$ the location and amount of land to be transferred; the interest to be transferred; the time of the transfer; the price; the uses to be prescribed or prohibited; the method of assuring use after disposition; and the process by which the transferee is selected. An individual disposition decision may be objectionable either because it causes misdevelopment or because it unjustifiably excludes some group or use.

Misdevelopment occurs when a disposition, or lack of disposition, is inconsistent with the legitimate legislative objectives of the land bank. ${ }^{30}$ One source of misdevelopment is official wrongdoing; officials in charge of land use regulation have been unusually susceptible to graft, conflict of interest, and political bias because of the large financial interests involved and the broad range of arguably correct decisions. ${ }^{31}$ Also, in land banking, developers seeking advantageous dispositions and public officials seeking personal or political profit may try to influence the timing and type of dispositions for personal gain. A less venal source of misdevelopment is disregard for planning considerations. Land use regulation has often been controlled by nonprofessionals who fail to consider the complex factors involved in regulation..$^{32}$ In addition, the actions of individual decision makers may be swayed by personal inclinations in favor of particular land use patterns.

Objections to a disposition may also be based on its exclusionary ef-

27 Id.

28 See M. CrAwson, supra note 9, at 360-61; Public Land Banking, supra note 2, at 945. The experience of land disposition in the federal urban renewal program is instructive. See U.S. Urban Renewal Administration, Urban Renewat Manual ch. 14 (1964); Brownfield \& Ecker, The Disposal of Urban Renewal Land and Land Use Planning, 10 WAYNE L. REV. 681 (1964).

20 See Ptedmont Triad Council of Governments, Land Bank Handbook B-7 to B-9 (C. Van Alstyne ed. 1972).

30 Terming this inconsistency "misdevelopment" is not intended to imply that there is only one pattern of dispositions that will achieve the desired objectives; there are likely to be several patterns consistent with the statutory goals.

31 American Soc'y of Planning Officials, supra note 2, at 45-46; Tent. Draft No. 5, supra note 3, at 56-57; cf. Ellickson, supra note 3, at $701 \mathrm{n} .73$.

32 American Soc'y of Planning Offictals, supra note 2, at 88-40; Public Land Banking, supra note 2, at 905-06. 
fect. ${ }^{33}$ The frequent efforts of suburban communities to protect their "tight little islands" 34 by exclusionary zoning indicates the importance of this problem. ${ }^{35}$ The absolute control over development offered by land banking makes it an ideal tool for various exclusionary purposes.

In a well-functioning system, judicial review will not be the primary constraint on land bank dispositions; decisions would be influenced primarily by specific statutory restrictions on dispositions ${ }^{36}$ and the procedures required for decision making. ${ }^{37}$ These controls alone are unlikely, however, to assure proper disposition of banked land. Experience has shown that even the most elaborate and carefully planned administrative procedures do not prevent improper action. ${ }^{38}$ In addition, legislation prescribing all disposition decisions in detail would deprive the land bank of needed flexibility. ${ }^{39}$ Judicial review will be needed to control dispositions that necessarily involve some exercise of discretion by regulatory officials.

33 Although virtually any group or use may be excluded, exclusion is used here to refer to restriction of low and moderate income housing, often with racially discriminatory effect, and to severe limitation of an area's population growth. National Land \& Inv. Co. v. Easttown Township Bd. of Adjustment, 419 Pa. 504, 553, 215 A.2d 597, 612 (1965); Note, Equal Protection and Exclusionary Zoning, 81 YALE L.J. 61, 62-63 (1971). These restrictions are the most likely to be in conflict with independent constitutional or statutory policies and, unlike exclusion of uses such as heavy industry, are likely to have little relation to the legitimate goals of the land banking system.

34 See Sager, Tight Little Islands: Exclusionary Zoning, Equal Protection, and the Indigent, 21 STAN. L. REv. 767 (1969).

35 See Sager, Exclusionary Zoning: Constitutional Limitations on the Power of Municipalities to Restrict the Use of Land, 1972 LAND-UsE CoNTROLS ANNUAL 153.

36 For example, under the Model Land Development Code land may not be transferred pursuant to negotiated sales tainted by conflict of interest. Reporters' Draft, supra note 26, at § 6-407(4). Other restrictions include a maximum period of time for which land may be held before disposition. P.R. LAws ANN. tit. 23, $\$ 311$ (q) (1964).

37 The Model Land Development Code provides a detailed description of decisionmaking procedures. The State Land Planning Agency must consent to all dispositions except public sales, transfers to government agencies, short-term leases, return of land to condemnees, and transactions concerning land held beyond the statutory period. Reporters' Draft, supra note 26 , at $\$ 6-401$. Specific procedures are mandated for other types of disposition. $Y d$. at $\$ \S 6-402$ to -407 . The most detailed provisions apply to disposition by negotiated purchase, because this area is subject to the greatest abuse. Id. at $\S 6-407$. After the State Land Reserve Agency negotiates with the proposed purchaser, the State Land Planning Agency holds a public hearing on all matters concerning the sale. The State Land Planning Agency approves the sale only if it finds the terms fair and in accordance with the development plan. Id.

38 For a discussion of the role of judicial review of actions in the administrative process, see L. JAFFE, supra note 5, at 320-27 (1965). The multitude of cases finding improper zoning decisions that were made in an elaborate procedural framework testify to the need for judicial scrutiny. E.g., Raabe v. City of Walker, 383 Mich. 165, 174 N.W.2d 789 (1970); Bosse v. City of Portsmouth, 226 A.2d 99 (N.H. 1967). The procedural framework of zoning is discussed in 1 R. ANDERson, AMERIGan LAw OF Zoning ch. 4 (1968).

39 The validity of this position has been recognized in existing land bank statutes. See, e.g., P.R. LAws ANN. tit. 23, \& $811 f$ (1964). 
The right to challenge a land disposition may be defined in the land bank enabling statute. ${ }^{40}$ In the absence of such a provision, the state statute or case law regulating review of administrative actions will prevail.41 The same parties are likely to be permitted to bring suit under either formulation, ${ }^{42}$ but an affirmative provision in the enabling statute may eliminate needless confusion.

Although constitutional limitations on land bank dispositions are inadequate,,$^{43}$ the courts have a number of possible models to draw on in determining the proper standard for nonconstitutional review of dispositions. For example, the courts could adopt either a substitution of judgment test or a standard involving deference to the disposition decision. Consideration of the nature of the development plan and disposition decisions ${ }^{44}$ and analogy to courts' review of zoning decisions ${ }^{45}$ suggest the appropriate standard of review.

\section{The Inadequacy of Constitutional Restraints ON LAND BANK Dispositions}

The United States Constitution and most state constitutions impose some restraints on land bank dispositions. ${ }^{46}$ The major constitutional limitations on dispositions depend to some extent on the method of government acquisition of the land being disposed of. Land may be

40 Tent. Draft No. 3, supra note 3, at \$ 9-103 suggests that a challenge to a disposition may be brought by any party to the hearing on the disposition before the land bank agency or by a party with significant interest that has been injured and that was not adequately represented in the administrative proceeding. Section 2-304(5) allows established community organizations and others with significant interests to participate in the hearings and thereby in a subsequent court proceeding.

41 In some states, this will require an express reference to the state administrative procedure law in the land bank statute. E.g., Irx. REv. STAT. ch. 110, $\$ 265$ (1971). In others, the land bank as a state agency will automatically be subject to the provisions for review. E.g., PA. Stat. ANv. tit. 71, \$§ 1710.2, 1710.41 (Purdon's 1962).

42 The Code's provision includes only one class whose standing would otherwise be questionable, community organizations. Recent exclusionary zoning trends indicate a judicial tendency to grant these groups standing. Elias, Significant Developments and Trends in Zoning Litigation, 1973 Instrutu on PLANning, Zoning, \& EMinent Domain 1. The Code's catch-all provision, granting standing to those parties with significant unrepresented interests that have been injured, is similar to the Model State Administrative Procedure Act's standing principle. Moder State Administrative Procedure Acr $\& 15(\mathrm{a})$ (1970).

43 See text and notes at notes 46-61 infra.

44 See text and notes at notes $65-73$ infra.

15 See text and notes at notes 74-146 infra.

46 This discussion deals only with the constitutional restrictions on land disposition. Other constitutional issues, such as the power of the legislature to delegate authority to the land bank, can arise. Nothing in the resolution of such issues is unique to land banking, so they are not considered here. Constitutional issues that might arise because of specific types of disposition are discussed at text and notes at notes 60-61 infra. 
acquired in two ways: by condemnation or by purchase that is voluntary on the part of the seller. ${ }^{47}$

Federal and state constitutions impose particular limitations on the disposition of land acquired through the exercise of eminent domain. ${ }^{48}$ Judicial interpretations of these restrictions, however, have resulted in a broad scope of permissible dispositions. ${ }^{49}$ The basic constitutional limitation on the power of a sovereign to condemn land is that the land must be taken for a public use or public purpose. ${ }^{50}$ This restraint limits disposition because land may not be condemned under the guise of a public purpose and then disposed of for a private use. An acceptable public use, as currently defined, must serve a legitimate governmental objective and be a reasonable means to achieve that objective. ${ }^{51}$ Courts give great deference to legislative definitions of public purposes and reasonable means to achieve those purposes. ${ }^{52}$ In land banking the legislative goals stated above are certainly legitimate public objectives, and individual dispositions are likely to be held reasonable means of serving those objectives. ${ }^{53}$ Constitutional restrictions on the eminent

47 See text and notes at notes 9-11 supra. It is not clear at present to what extent each method of acquisition will be used. Eminent domain may be necessary only to acquire the last parcel of land from a holdout owner seeking to extort a high price from the government. The threat of condemnation and the lower price it usually brings may be enough to force most owners to sell voluntarily. The type of acquisition may depend on whether the land bank acquires the land secretly through agents or after an open announcement of purpose; the latter course of action might tend to elevate the price.

48 Missouri Pac. Ry. v. Nebraska, 164 U.S. 403 (1896); Nichols, The Meaning of Public Use in Eminent Domain, 20 B.U.L. REv. 615 (1940).

49 F. Bosselman, D. Carlies, \& J. Banta, The Takng Issue (1973); Sax, Takings, Private Property and Public Interests, 81 YaLE L.J. 149 (1971); Comment, The Public Use Doctrine: "Advance Requiem" Revisited, 1969 LAW \& Soc. ORDER 688.

50 Berman v. Parker, 348 U.S. 26 (1954); Missouri Pac. Ry. v. Nebraska, 164 U.S. 403 (1896); 1 J. Lewis, Eminent Domain $\S 250$ (3d ed. 1909).

51 See Berman v. Parker, 348 U.S. 26, 31-34 (1954).

52 Subject to specific constitutional limitations, when the legislature has spoken, the public interest has been declared in terms well-nigh conclusive. In such cases the legislature, not the judiciary, is the main guardian of the public needs to be served by social legislation, whether it be Congress legislating concerning the District of Columbia or the States legislating concerning local affairs. This principle admits of no exception merely because the power of eminent domain is involved. The role of the judiciary in determining whether that power is being exercised for a public purpose is an extremely narrow one.

Id. at 32.

53 The Puerto Rico land banking system was upheld on this basis in Commonwealth v. Rosso, 95 P.R.R. 488 (1967):

Once there has been a legislative declaration or declaration by the delegated entity that there is a public utility, within the present meaning of the concept, the courts cannot intervene with the manner and the means which the legislature or its delegated entitites choose to exercise the power of condemnation, nor with the selection made respecting what properties are to be condemned.

Id. at 524 .

The level of reasonable relation that must be established here is considerably lower than 
domain power will thus invalidate only the most flagrant misuses of condemned land.

However land is acquired, land banking is subject to a constitutional limitation because it is an exercise of the police power. ${ }^{54}$ The principal limitation on that power requires that it be exercised reasonably ${ }^{55}$ and for the public welfare. ${ }^{56}$ The public welfare restriction, like the public purpose requirement applied to land obtained by eminent domain, is generally easily satisfied. ${ }^{67}$ Similarly, the reasonableness test, like the reasonable means test applied to land obtained by eminent domain, usually will not be a significant restriction. 58 The reasonableness test, however, is more strictly applied where dispositions achieve the exclusion of certain racial or economic groups from a region. The exercise of the police power in such a discriminatory manner has been held to be a denial of due process in zoning cases, ${ }^{59}$ and discrimination in disposition by the land bank is also proscribed.

Land banking is also subject to restrictions imposed by the equal protection clause of the fourteenth amendment to the Constitution. Challenges will probably arise when dispositions allegedly discriminate unlawfully against economic groups. ${ }^{60}$ All dispositions that establish prices for land and subsequent uses discriminate to some extent, but the point at which discrimination becomes constitutionally impermissible is difficult to determine. ${ }^{61}$ Full discussion of this issue is beyond the scope of

that embodied in the "fairly debatable" standard used for review of the relation of land dispositions to statutory objectives. See text and notes at notes 90-91 infra.

54 [T] police, including in that general designation whatever will promote the peace, comfort, convenience, and prosperity of their people." Escanaba Co. v. Chicago, 107 U.S. 678, 683 (1882).

55 Goldblatt v. Town of Hempstead, 369 U.S. 590, 594-95 (1962); Lawton v. Steele, 152 U.S. 139, 137 (1894).

56 Chicago \& AIton R.R. v. Tranbarger, 238 U.S. 67, 76-77 (1915).

57 See Queenside Hills Realty Co. v. Saxl, 328 U.S. 80, 83 (1946); Galvan v. Superior Court, 70 Cal. 2d 851, 869, 452 P.2d 930, 942, 76 Cal. Rptr. 642, 654 (1969).

58 See, e.g., Sproles v. Binford, 286 U.S. 374, 388-89 (1932).

59 In re Kit-Mar Builders, $439 \mathrm{~Pa}$. 466, 268 A.2d 765 (1970); National Land \& Inv. Co. v. Easttown Township Bd. of Adjustment, 419 Pa. 504, 215 A.2d 597 (1965).

60 Cf. Kennedy Park Homes Ass'n v. City of Lackawanna, 318 F. Supp. 669 (W.D.N.Y.), aff'd, 496 F.2d 108 (2d Cir. 1970), cert. denied, 401 U.S. 1010 (1971); Dailey v. City of Lawton, 296 F. Supp. 266 (W.D. Okla. 1969), aff'd, 425 F.2d 1037 (10th Cir. 1970).

61 A complicating factor is that the test for denial of equal protection is presently unclear. See generally San Antonio Ind. School Dist. v. Rodriguez, 411 U.S. 1 (1973) (opinion of the Court by Powell, J.); id. at 70 (Marshall, J. dissenting); Gunther, The Supreme Court, 1971 Term-Foreword: In Search of Evolving Doctrine on a Changing Court: A Model for a Newer Equal Protection, 86 HARv. L. Rev. 1 (1972). Under the traditional test, those alleging unconstitutionality would have to establish that there was no rational relation between the purposes of land banking and the disposition or that the disposition was grounded on a suspect classification or infringed fundamental personal rights. Develop- 
this comment; it is sufficient to note that only in extreme cases will dispositions be subject to invalidation as denying equal protection to certain economic groups.

The ease with which the constitutional requirements on land banking are met suggests that they do not provide adequate protection against misuse of land banking authority.

\section{Nonconstitutional Review of Misdevelopment}

The basic nonconstitutional limitation on the disposition of banked land is that the disposition be within the statutory authorization. ${ }^{62}$ Dispositions will be authorized only if they further the statutory objectives of the system. The purpose of this section is to define a technique of judicial review by which a court may determine whether a particular disposition complies with the statutory objectives.

\section{A. Judicial Review Under the Development Plan}

The purpose of the land bank development plan is to achieve in the specific area to be developed ${ }^{63}$ the general objectives outlined in enabling legislation. Many land dispositions will be either directed by or in conflict with the plan, ${ }^{64}$ and the plan will provide some indication of whether a challenged disposition is consistent with the statutory objectives. To determine the weight to be given the plan, it is necessary to determine whether it should be classified as a legislative rule that defines the objectives or an interpretative rule that does not have the force of law. ${ }^{65}$

The plan will usually not be a legislative rule. ${ }^{86}$ An agency may issue

ments in the Law - Equal Protection, 82 HARv. L. Rev. 1065 (1969). The land bank would generally be able to satisfy the rational relation test. Recent decisions discussing wealth and race as suspect classifications and housing as a fundamental interest cast doubt on the likelihood of finding a denial of equal protection in any but extreme cases. See San Antonio Ind. School Dist. v. Rodriguez, supra; Jefferson v. Hackney, 406 U.S. 535 (1972); Lindsey v. Normet, 405 U.S. 56 (1972); James v. Valtierra, 402 U.S. 137 (1971); Dandridge v. Williams, 397 U.S. 471 (1970). See-Comment, Equal Protection and Exclusionary Zoning, 81 YALE L.J. 61 (1971). In the land bank case there will frequently not even be a definable class that has been singled out for discrimination. See id. at 77 . Where equal protection review is ineffective, the antipresumption review technique may be used to prevent improper dispositions. See text and notes at notes 127-46 infra.

62 See text and notes at notes 86-88 infra.

63 See text and notes at notes 17-18 supra.

64 But see text at note 100 infra.

65 See Gibson Wine Co. v. Snyder, 194 F.2d 329, 331-32 (D.C. Cir. 1952); Comptroller of the Treasury v. M.E. Rockhill, Inc., 205 Md. 226, 234, 107 A.2d 93, 98 (1954); I K. Davis, Administrative LaW Treatise $\$ 5.03$ (1958).

66 If the development plan were characterized as a legislative rule, there would be a 
a legislative rule only if there is a grant of authority by the legislature to the agency to make rules having the force of law, ${ }^{67}$ and land bank statutes generally do not grant such authority. ${ }^{68}$ In the typical case, the development plan must therefore be treated as an interpretative rule. The issue for the courts is then the extent to which they should accept the specific requirements of the plan as an expression of the statutory objectives.

Two factors inherent in the development plan suggest that the court should give it substantial weight in reviewing a specific disposition. First, courts have generally recognized that they must refrain from substitution of judgment in matters of agency expertise. ${ }^{69}$ The creation of a development plan that will achieve the statutory objectives requires both technical expertise and an understanding of the competing public interests that will be affected, ${ }^{70}$ and it will generally be beyond the competence of a court to evaluate such a plan. ${ }^{71}$

The second factor suggesting that judicial deference is appropriate is thoroughness in the consideration and adoption of the plan. ${ }^{2}$ The formulation of the plan is preceded by a comprehensive study of the current and future needs and conditions of the area. The plan is con-

limited scope of review: whether the rule is within the power of the agency, is reasonable, and was issued by proper procedure. $1 \mathrm{~K}$. DAvis, supra note 65 , at $\$ 5.05$; cf. In re DaLomba's Case, 352 Mass. 598, 603, 227 N.E.2d 513, 517 (1967).

67 I K. DAvis, supra note 65 , at $\$ 5.05$.

68 Some land bank statutes, for example those of Kentucky and Puerto Rico, contain no provision at all for the making of a development plan. Others authorize planning in language that makes the effect of the plan unclear. The Ohio statute, for example, empowers the agency to "[e]ngage in planning for the new community district, and prepare or approve a development plan therefore, and engage in land acquisitions and land development in accordance with such plan or plans," OHIo Rev. CoDE ANN. \& 349.06(O) (Page Supp. 1973), but also authorizes the agency to acquire and dispose of land "on such terms and in such manner as it considers proper." Id. \& 349.06 (A) \& (B). It is probably undesirable to give the plan the force of law in reviewing dispositions; no planning document should be enshrined as a legislative plan, because development planning for the land bank is an ongoing process. See text and notes at notes 17-18 supra. Treating the plan as an interpretative rule gives weight to planning in review of dispositions but does not preclude flexibility. See generally F. Chapin, Urban Land Use Planning (1965).

If the development plan were characterized as legislative, dispositions would still ultimately be judged against the legislative objectives. A legislative rule must be within the authority of the agency, so a plan that did not accord with the objectives would be of no weight either in support of or in opposition to a disposition. Commonwealth v. DiMeglio, 385 Pa. 119, 122 A.2d 77 (1956).

60 E.g., Langen v. Badlands-Co-operative State Grazing Dist., 125 Mont. 302, 309, 234 P.2d 467, 471 (1951). Where the technical nature of the matter requires uniformity of policy there is an additional measure of hesitance. Id. This factor obviously applies to a development plan, where regional uniformity is mandatory.

70 see F. Chapin, supra note 68 , at 7-68.

71 Cf. LA. Rev. Stat. ANN. \& 7603(15); Tent. Draft No. 3, supra note 3, at § 8-402.

72 Cf. Skidmore v. Swift \& Co., 323 U.S. 134, 140 (1944). 
structed only after consideration of all relevant information. Adoption of a development plan will usually require compliance with elaborate administrative procedures, including public distribution, hearings, opportunity for public comment, and review by higher authorities. ${ }^{73}$ These procedures give the plan many of the attributes of a legislative rule and suggest that it should be accorded substantial deference.

An examination of the principles applied in zoning law also indicates that the development plan should be given great weight in review of dispositions. This examination is appropriate because of the parallels between the land bank development plan and the zoning ordinance. In both zoning and land banking a general scheme for land use control $^{74}$ is adopted through a legislative-type process ${ }^{75}$ pursuant to a legislative grant of authority ${ }^{76}$ in furtherance of certain public objectives. ${ }^{77}$ Actions may be taken under the guidance of the general scheme ${ }^{78}$ or as a change in policy; ${ }^{79}$ the general plan is not strictly binding. ${ }^{80}$ Challenges to specific actions must allege that there is deviation from the

73 See, e.g., Tent. Draft No. 3, supra note 3, at § 8-405.

$74 \mathrm{~A}$ key purpose of land banking is control of land development in a rational way through a general plan. See text and note at note 12 supra. The Standard State Zoning Enabling Act requires that zoning be done "in accordance with a comprehensive plan;" the enabling legislation of forty-four states includes that or a similar provision. 1 R. ANDERSON, supra note 38 , at § 5.02 .

75 The procedure for adopting a land bank development plan is discussed in text and notes at notes 72-73 supra. The adoption of a zoning ordinance is always a legislative act. See, e.g., Orth v. Board of County Comm'rs, 158 Colo. 540, 545, 408 P.2d 974, 977 (1965).

76 For a discussion of the agencies to which land banking powers can be delegated and their authority, see text and notes at notes 9-11 supra. Every state legislature has delegated the power to zone to municipal governments. 1 R. ANDERson, supra note 38, at \$ 3.09. There has been little dispute over the legitimacy of this delegation. See, e.g., In re Opinion of the Justices, 124 Me. 501, 509, 128 A. 181, 185 (1925).

77 The zoning power is exercised, in general terms, for the public welfare. Gibbons \& Reed Co. v. North Salt Lake City, 19 Utah 2d 329, 332, 431 P.2d 559, 562 (1967). The land bank objectives are discussed at notes 12-16 supra, and their implications at notes 17-18 supra. While these objectives are not as broad as the "public welfare," they are usually phrased in language broad enough to approach that concept. E.g., Statement of Motives, P.R. Acts, May 16, 1962, No. 3.

78 The land bank development plan may direct a disposition pattern. In zoning cases, amendments have been upheld where they were enacted pursuant to the community's comprehensive plan. Malafronte v. Planning and Zoning Bd., 155 Conn. 205, 230 A.2d 606 (1967).

79 Changed conditions may require an alteration of the land bank's policy. This policy is as valid here as in the case of a zoning amendment: "There can be no question but that the municipality has the right to amend its zoning ordinance from time to time as new and changing conditions warrant and require such revision. . . . To hold otherwise would be to fix cities' development in the mould of the first zoning ordinances enacted." Jardine v. City of Pasadena, 199 Cal. 64, 76, 248 P. 225, 229 (1926).

80 The land bank agency is usually not authorized by statute to create a binding plan. See text and notes at notes $66-68$ supra. As discussed in note 79 supra, the comprehensive zoning plan may be amended as required. 
general plan in a manner that conflicts with the legitimate objectives of the activity. ${ }^{81}$

Early zoning cases, because of the merely semi-official status of master plans $^{82}$ and a general judicial distrust of planning, ${ }^{83}$ gave master zoning plans little weight. As a practical matter, this result was appropriate; in the early period of zoning, many zoning governments were without professional planning expertise. ${ }^{84}$ As such expertise has become more readily available, however, plans have been given greater weight in reviewing zoning actions. ${ }^{85}$

A zoning ordinance is normally presumed to be a valid exercise of the authority delegated to the zoning government. ${ }^{86}$ The general principle is that an ordinance will not be invalidated so long as it is within the realm of fair debate that the ordinance reasonably serves the objectives of zoning. ${ }^{87}$ This principle is derived from the basic concept that, within constitutional limits, the determination of questions of land control policy is properly for the legislature and the authorities to which the questions are delegated, not for the courts. ${ }^{88} \mathrm{~A}$ court reviewing a land bank disposition should likewise respect the legislative delegation of the responsibility to determine development policy. After it has been determined that the plan is to be given significant weight in a determination of the specific objectives of the system, it is necessary to examine the precise way in which the courts should undertake review of specific dispositions.

1. Dispositions Directed by the Development Plan. Land dispositions, like other exercises of the police power, should initially be presumed to be in furtherance of legitimate statutory policies. ${ }^{89}$ The plaintiff attacking a disposition will then bear the burden of persuading the

81 As to land banking, see text and notes at notes 30-32 supra. The allegation in a spot zoning case is that the government has singled out the property of an individual for special benefit in derogation of the general zoning scheme and the public welfare. Rodgers v. Village of Tarrytown, 302 N.Y. 115, 123, 96 N.E.2d 731, 734 (1951).

82 Cf. D. Hagman, Urban Planning and Land Development Control Law \& 12 (1971).

83 See, e.g., Lordship Park Ass'n v. Board of Zoning Appeals, 137 Conn. 84, 75 A.2d 379 (1950).

84 Haar, "In Accordance With a Comprehensive Plan," 68 HARv. L. REv. 1154, 117073 (1955).

85 E.g., Aspen Hill Venture v. Montgomery County Council, 265 Md. 308, 314-15, 289 A.2d 303, 309 (1972).

86 See, e.g., Levitt v. Sands Point, 6 N.Y.2d 269, 160 N.E.2d 501, 189 N.Y.S.2d 212 (1959).

87 See, e.g., Stevens v. Huntington, 20 N.Y.2d 352, 355, 229 N.E.2d 591, 593283 N.Y.S.2d

16, 18, (1967). See generally 1 R. ANDERson, supra note 38 , at $\$ 2.16$. Other principles are discussed $i d$. \$\$ 2.17-2.18.

88 Cf. Village of Euclid v. Ambler Realty Co., 272 U.S. 365,388 (1926).

89 Cf. State v. Grant, 107 N.H. 1, 3, 216 A.2d 790, 791 (1966); State v. Hudson House, Inc., 231 Ore. 164, 171, 371 P.2d 675, 679 (1962). 
court that the disposition is not within the prescribed aims of land banking. ${ }^{90}$ The land bank will be able to support the validity of the disposition by showing that it is directed by the development plan. The plan provides substantial evidence of the validity of the disposition within the legislative policy. ${ }^{91}$ The plaintiff may rebut the effect of the plan by showing that the development plan, or at least the portion of it relating to the disposition in question, does not in fact accord with the legislative objectives. ${ }^{92}$ Attacking the plan itself, however, is a much heavier burden for the plaintiff to meet than simply demonstrating that a particular disposition is not within the statutory objectives. ${ }^{93}$ The plan thus increases significantly the plaintiff's burden where the particular disposition is directed by the plan.

2. Dispositions Inconsistent with the Development Plan. One doctrine employed in spot zoning cases-the change or mistake ruleplaces primary importance on the comprehensive plan $^{94}$ in defining the validity of an amendment to the zoning ordinance, but still allows some flexibility. A municipal zoning body may amend its zoning ordinance on a showing of a mistake in the original enactment of the ordinance or changed conditions in the area. ${ }^{95}$ The rationale for the change or mistake rule is that a decision concerning a proper use of land that is inconsistent with the determination embodied in the orignal ordinance is inherently suspect. ${ }^{96}$ The party favoring the amendment bears the burden of showing the existence of a change or mistake sufficient to justify such an inconsistency.

A similar doctrine is appropriate in the case of an attack on a disposition inconsistent with the development plan. The challenger would bear the initial burden of showing a conflict between the disposition and the plan. The burden then shifts to the land bank to establish that

90 See text and notes at notes 86-88 supra.

91 See text and notes at notes 63-85 supra.

92 For example, a plan that originally served the legislative policy may be shown to no longer do so because of changed circumstances.

93 See text and notes at notes 63-85 supra.

94 The comprehensive plan here need not be the formal master plan; it may be the court's view of the general plan contained in the zoning ordinance. See MacDonald v. Board of County Comm'rs, 238 Md. 549, 555, 210 A.2d 325, 328 (1965).

95 The change or mistake rule has had its greatest impact in Maryland. See, e.g., id.; 1 R. ANDERson, supra note 38, at $\$ 4.29$. Under the Maryland rule supporters of the zoning amendment must establish (I) what area reasonably constitutes the "neighborhood" of the property affected; (2) the changes that have occurred; and (3) that these changes have significantly altered the character of the neighborhood. Montgomery v. Board of County Comm'rs, $256 \mathrm{Md}$. 597, 602, 261 A.2d 447, 450 (1970), rev'd on appeal from remand, 263 Md. 1, 280 A.2d 901 (1971).

96 See Whittle v. Board of Zoning Appeals, 211 Md. 36, 45, 125 A.2d 41, 46 (1956). 
the particular disposition complies with the statutory objectives despite conflict with the development plan. Although there are likely to be several possible dispositions that comply with the statutory objectives, the change or mistake doctrine presumes that the plan expresses the disposition pattern that most fully complies with the statute and requires that changed circumstances ${ }^{97}$ or the need to correct a mistake ${ }^{98}$ justify any inconsistencies between the disposition and the plan. Application of this doctrine would limit ill-considered or improperly motivated dispositions and would encourage the land bank to engage in continuing planning, with periodic revisions of the plan as conditions change. ${ }^{99}$

\section{B. Judicial Review of Discretionary Dispositions}

In practice, few cases will involve dispositions that clearly are directed by or in conflict with the development plan. Many parts of the plan will define only general goals, or provide a number of options, thus leaving the land bank with considerable discretion over particular dispositions. In these cases, the courts should draw on review techniques developed in spot zoning cases.

Spot zoning involves amendments to a general zoning ordinance that affect small parcels of land. An amendment may represent either a change in policy due to changed circumstances in the community $y^{100}$ or the first time a land use policy is affirmatively applied to a tract. ${ }^{101}$ The latter is often the case where land in a developing area is changed from an agricultural or other holding classification to a developable category, ${ }^{102}$ similar to the land bank's disposition of land formerly in a holding zone.

A spot zoning amendment is always a legislative act. ${ }^{103} \mathrm{~A}$ particular land bank disposition may be legislative or administrative, depending on the form of the land bank agency. The definition of general disposition patterns will nearly always be legislative in nature, ${ }^{104}$ but particular dispositions not prescribed in the plan may be ordered by agency offi-

97 E.g., Montgomery v. Board of County Comm'rs, 263 Md. 1, 280 A.2d 901 (1971).

98 E.g., Overton v. Board of County Comm'rs, 225 Md. 212, 170 A.2d 172 (1961).

08 Such periodic revision must adhere to the standards set for the adoption of the original plan. See text and notes at notes 72-73 supra; cf. Dalton v. Honolulu, 51 HAw. 400, 462 P.2d 199 (1969).

100 E.g., Thomas v. Town of Bedford, 11 N.Y.2d 428, 184 N.E.2d 285, 230 N.Y.S.2d 684 (1962).

101 E.g., McQuail v. Shell Oil Co., 40 Del. Ch. 396, 183 A.2d 572 (Sup. Ct. 1962).

102 Id.

103 Fusco v. Town of Oyster Bay, 23 Misc. 2d 72, 74, 200 N.Y.S.2d 567, 570 (Sup. Ct. 1960).

104 A legislative act of the land bank agency, however, rather than of the state legislature. 
cials. Even where the disposition decision is made by an official, however, it will have a legislative-type purpose-the achievement of general public objectives - rather than the administrative-type purpose of alleviation of special hardship on individuals, as is the case, for example, with zoning variances. ${ }^{105}$

The general test used by courts in reviewing spot zoning amendments is whether it is fairly debatable that the amendment is related to the general welfare..$^{100}$ In applying this test, the courts generally impose three requirements that are particularly useful in review of land bank dispositions. First, there must be substantial evidence that the action is reasonable. ${ }^{107}$ Second, the way in which the determination is made must be indicative of a reasoned decision. ${ }^{103}$ Third, the action must not be solely for the benefit of an individual or small group..$^{109}$

1. Substantial Evidence of Reasonableness. Under the first test for spot zoning, there must be substantial evidence that the amendment is a reasonable exercise of the police power. ${ }^{110}$ Many factors are considered relevant to this determination. ${ }^{111}$ Often mentioned are the density and nature of surrounding land, ${ }^{112}$ the relation between the amended use and surrounding uses, ${ }^{113}$ the needs of the area, ${ }^{114}$ the availability of public services, ${ }^{115}$ and the effect of the change in use on the value of neighboring property. ${ }^{116}$

In the case of land banking it is similarly appropriate to require substantial evidence of compliance with statutory objectives. Because the land involved will usually be less developed than in zoning cases, different factors will be relevant. The needs of the region for the use pre-

105 An analogy to variances or special exceptions, for example, would be improper because these techniques provide relief from zoning restrictions that impose unusual practical difficulties and unnecessary hardships on a landowner. Sinclair Pipe Line Co. v. Village of Richton Park, 19 III. 2d 370, 373, 167 N.E.2d 406, 408 (1960). By their very nature variances are inconsistent with the planned control of land; they are tolerated in zoning because of the unusual personal hardship imposed, but are unnecessary in land banking.

100 See text and note at note 87 supra.

107 See text and notes at notes 110-116 infra.

108 See text and notes at notes 117-122 infra.

109 See text and notes 123-126 infra.

110 Eckes v. Board of Zoning Appeals, 209 Md. 432, 121 A.2d 249 (1956); Rodgers v. Village of Tarrytown, 302 N.Y. 115,96 N.E.2d 731 (1951).

111 See generally 1 R. ANDERson, supra note 38 , at $\$ 5.05$.

112 Malafronte v. Planning and Zoning Bd., 155 Conn. 205, 211, 230 A.2d 606, 610 (1967).

113 Buell v. Gity of Bremerton, 80 Wash. 2d 518, 526, 495 P.2d 1358, 1363 (1972).

114 Durand v. Superintendent of Public Bldgs., 354 Mass. 74, 75, 235 N.E.2d 550, 552 (1968).

115 De Meo v. Zoning Comm'n, 148 Conn. 68, 167 A.2d 454, 457 (1961).

116 Willott v. Village of Beachwood, 175 Ohio St. 557, 559, 197 N.E.2d 201, 204 (1964). 
scribed in the disposition, the availability of alternative parcels, and the relation of the disposition to other proposed or actual uses in the area are likely to be particularly significant considerations.

2. Procedural History of the Disposition Decision. As professional planning expertise has become available to zoning governments, courts have increasingly recognized its usefulness in the making of zoning decisions. ${ }^{117}$ A zoning amendment is more likely to be upheld if it is based on a history of serious consideration and consultation among the governing authorities, professional planners, and the public..118 Where a decision is made abruptly and without consultation or procedural safeguards, however, courts are more likely to find the amendment arbitrary and therefore invalid. ${ }^{110}$

In land bank cases the procedural history of a disposition decision should similarly be relevant to the validity of the disposition. Where a formal decision procedure is prescribed in the enabling statute, the court should require that it be followed. ${ }^{120}$ Where no procedure is mandated, the court may require procedures that provide for full consideration and careful action. ${ }^{121}$ Consultation with expert planners, opportunity for inputs by concerned groups, and findings and reasons would be relevant procedural steps. ${ }^{122}$

3. Apparent Benefit. In reviewing zoning amendments, courts have considered whether an amendment is invalid because made for private rather than public benefit. ${ }^{123}$ The basic inquiry is whether the action serves no general public purpose, but instead singles out one party for special benefit. ${ }^{124}$ The subjective motives of zoning officials are irrelevant, ${ }^{125}$ but a clear showing of apparent impropriety is sufficient to invalidate an amendment. If, in viewing all the evidence relating to a zoning amendment, the court finds more than incidental benefit to the property owner involved, a finding of invalidity may be appropriate. ${ }^{126}$

117 See, e.g., Albright v. Town of Manlius, 28 N.Y.2d 108, 268 N.E. 2d 785, 320 N.Y.S.2d 50 (1971). See generally 1 R. ANDERson, supra note 38, at $\$ 5.13$.

118 E.g., West Ridge, Inc. v. McNamara, 222 Md. 448, 160 A.2d 907 (1960); Twenty-One White Plains Corp. v. Village of Hastings-on-Hudson, 14 Misc. 2d 800, 180 N.Y.S.2d 13 (Sup. Ct. 1958), aff'd, 9 App. Div. 2d 934, 196 N.Y.S.2d 562 (1959).

110 E.g., Smith v. Skagit County, 75 Wash. 2d 715, 453 P.2d 832 (1969).

120 See, e.g., Reporters' Draft, supra note 26, at \$§ 6-403, 6-406.

121 For example, the Model Land Development Code gives the State Land Reserve Agency considerable discretion in making negotiated dispositions. Reporters' Draft, supra note 26 , at $\$ 6-407$. The court can require that this discretion be structured and confined. See K. Davis, Administrative Law: Cases-Texr-Problems 448 (1973).

122 See generally id. at 520-24.

123 See generally 1 R. ANDERson, supra note 38 , at § 5.05.

124 Kuehne v. Town Council, 136 Conn. 452, 460, 72 A.2d 474, 478 (1950).

125 Strandberg v. Kansas City, 415 S.W.2d 737, 742 (Mo. 1967).

120 Vece v. Zoning and Planning Comm'n, 148 Conn. 500, 172 A.2d 619, 621 (1961). For 
Since land banking is designed to achieve public goals, a disposition primarily made for private benefit should similarly be invalidated. Incidental benefit to the land transferee is not decisive; a disposition is not automatically outside the legitimate aims of the land bank merely because a developer profits from it. Where there is clear evidence, however, that the disposition favors the developer in derogation of the legislative policy, the court may properly hold the disposition invalid.

Judicial review of a discretionary disposition should not involve assessment of the correctness of the decision as part of the development policy, but the courts should determine whether a disposition is reasonably related to the statutory objectives of the land bank. An examination of the nature of the evidence supporting the disposition, the way in which it was made, and the apparent motive for the disposition will provide adequate review of discretionary dispositions without usurping the land bank's authority.

\section{Judicial Review of Exglusionary Dispositions}

The judicial review procedures described in the previous sections are designed to prevent dispositions of banked land in conflict with the statutory objectives of the land bank. A broader problem arises when the land bank engages in a pattern of dispositions that does not directly conflict with the enabling statute, but instead excludes or severely limits uses favored by other state policies. A limited number of exclusionary patterns may be forbidden by the state or federal constitutions, for example, where exclusion of low-income housing creates a racially discriminatory pattern. ${ }^{127}$ Many exclusions or limitations, however, will restrict uses such as trailer parks, moderate income housing units, or schools; these uses may be favored by state policies, but they are not constitutionally protected. Exclusion of these uses could be consistent with the enabling statute and directed by the development plan. Under the tests designed for review of misdevelopment, such exclusions would often be found valid. Other principles of review, however, indicate that such exclusionary patterns may be invalidated.128

Again, zoning law provides a useful analogy. A general principle of zoning review, recently used in exclusionary zoning cases, is known as the antipresumption. ${ }^{129}$ Where a local zoning action conflicts with a

an extreme case, see Blumberg v. City of Yonkers, 21 App. Div. 2d 886, 251 N.Y.S.2d 750 (1964), aff'd, 15 N.Y.2d 791, 205 N.E.2d 686, 257 N.Y.S.2d 589 (1965).

127 See, e.g., Kennedy Park Homes Ass'n v. City of Lackawanna, 318 F. Supp. 669 (W.D.N.Y.), aff'd, 436 F.2d 108 (2d Cir. 1970), cert. denied, 401 U.S. 1010 (1971); Dailey v. City of Lawton, 296 F. Supp. 266 (W.D. Okla. 1969), aff'd, 425 F.2d 1037 (10th Cir. 1970).

128 See text and notes at notes $129-46$ infra.

129 The designation "antipresumption" was applied in Feiler, Metropolitanization and 
state policy favoring a particular use, the antipresumption imposes on the local body the burden of justifying its action. The antipresumption is used to deal with exclusion of favored uses such as schools, ${ }^{130}$ hospitals, ${ }^{131}$ and public utilities. ${ }^{132}$ Where such uses are excluded, the antipresumption provides legal recognition of the fact that the conflict is between state and local policies, not between an individual's needs and the local government's policies. ${ }^{133}$

To bring the antipresumption into effect, the plaintiff challenging a use restriction must show that there is a general exclusion of that use and that the excluded use is favored by a state public policy. ${ }^{134}$ State policy may be expressed in state constitutional provisions, statutes, or judicial precedents. ${ }^{136}$ The use must be totally excluded or allowed only in minimal quantities that are equivalent to exclusion..$^{136}$ When a restriction is shown to be exclusionary in violation of a state policy, the action loses its normal presumption of validity, and the burden is shifted to the municipality to demonstrate a substantial relationship between the restriction and the local public welfare. ${ }^{137}$

The leading case on the antipresumption as applied to exclusionary zoning is Bristow $v$. City of Woodhaven, ${ }^{138}$ in which the plaintiff owned

Land-Use Parochialism-Toward a Judicial Attitude, 69 Mick. L. REv. 655 (1971), cited in Bristow v. City of Woodhaven, 35 Mich. App. 205, 211, 192 N.W.2d 322, 325 (1971). Cf. 9 J. WIGMORE, EvIDENCE § 2493 (3d ed. 1940).

130 Diocese of Rochester v. Planning Bd., 1 N.Y.2d 508, 136 N.E.2d 827, 154 N.Y.S.2d 849 (1956).

131 Wilmington v. Turk, 14 Del. Ch. 392, 129 A. 512 (Ch. 1925).

182 Consolidated Edison Co. v. Village of Briarcliff Manor, 208 Misc. 295, I44 N.Y.S.2d 379 (Sup. Ct. 1955).

133 The antipresumption in effect reads general state policies into the land bank enabling statute, but allows more flexibility than if such policies were directly and deliberately incorporated into the statute.

134 Bristow v. City of Woodhaven, 35 Mich. App. 205, 211, 192 N.W.2d 322, 325 (1971).

135 See text and notes at notes 141-146 infra.

136 Binkowski v. Township of Shelby, 46 Mich. App. 451, 467, 208 N.W.2d 243, 251 (1973).

137 Id. at 461-62, 208 N.W.2d at 248-49; Congregation Dovid Ben Nuchim v. Oak Park, 40 Mich. App. 698, 700, 199 N.W.2d 557, 559 (1972). The antipresumption cases do not agree on the burden that is shifted to the municipality. The leading cases in Michigan and Pennsylvania are unclear on whether a burden of persuasion or a burden of producing evidence shifts to the government. Bristow v. City of Woodhaven, $35 \mathrm{Mich}$. App. 205, 192 N.W.2d 322 (1971); Beaver Gasoline Co. v. Osborne Borough, 445 Pa. 571, 285 A.2d 501 (1971). Subsequent cases are divided on the issue. Compare Smookler v. Township of Wheatfield, 46 Mich. App. 162, 163, 207 N.W.2d 464 (1973), and Sauer v. Richland Township, 8 Pa. Comm. 464, 467 (Comm. Ct. 1973), with Johnson v. Township of Lyon, 45 Mich. App. 491, 493, 206 N.W.2d 761, 763 (1973). Shifting the burden of persuasion would require the land bank to affirmatively justify its action in opposition to a state policy and not merely to adduce some evidence in support of its disposition.

13835 Mich. App. 205, 192 N.W.2d 322 (1971). The Pennsylvania Supreme Court adopted the antipresumption in Beaver Gasoline Co. v. Osborne Borough, $445 \mathrm{~Pa}$. 571, 285 A.2d 
land that he wished to sell for use as a mobile home park. A city ordinance limited the number of trailers allowed in such a park to seventyfive, a restriction that made use of the land as a park economically unfeasible. Plaintiff challenged the refusal of the city to amend the ordinance, and the Michigan Court of Appeals affirmed the lower court's invalidation of the restriction. The use of land for a trailer park was recognized as legitimate and favored by the state. ${ }^{139}$ The de facto exclusion of trailer parks by the local government was held to be the equivalent of a declaration that trailer parks were nuisances and detrimental to the general welfare, ${ }^{140}$ and an antipresumption arose. The city failed to demonstrate a substantial relationship between the ordinance and the local public welfare, and the restriction was held invalid.

The Bristow court described the means by which a use achieves favored or preferred status. First, certain uses are recognized as bearing such "a real, substantial, and beneficial relationship to the public health, safety, and welfare"141 that they are favored by courts. ${ }^{142}$ In addition, the state constitution may encourage certain uses ${ }^{143}$ and state legislation "which is not merely for licensing or regulatory purposes but which purports to promote and encourage the good and well being of the general public" also confers preferred status. ${ }^{144}$ Finally, regulation of a use by the state and a critical public need may cause it to be favored by the courts. ${ }^{145}$ This situation existed in Bristow, where mo-

501 (1971). The Michigan courts following Bristow have developed the antipresumption more extensively than the Pennsylvania courts following Beaver Gasoline. Binkowski v. Township of Shelby, 46 Mich. App. 451, 208 N.W.2d 243 (1973); Sabo v. Township of Monroe, 46 Mich. App. 344, 208 N.W.2d 57 (1973); Smookler v. Township of Wheatfield, 46 Mich. App. 162, 207 N.W.2d 464 (1973); Johnson v. Township of Lyon, 45 Mich. App. 491, 206 N.W.2d 761 (1973); George v. Township of Harrison, 44 Mich. App. 357, 205 N.W.2d 254 (1973); Rodd v. Township of Palmyra, 42 Mich. App. 434, 202 N.W.2d 446 (1972); Congregation Dovid Ben Nuchim v. Oak Park, 40 Mich. App. 698, 199 N.W.2d 557 (1972); Green v. Township of Lima, 40 Mich. App. 655, 199 N.w.2d 243 (1972); Cohen v. Township of Canton, 38 Mich. App. 680, 197 N.W.2d 101 (1972); Simmons v. Royal Oak, 38 Mich. App. 496, 196 N.W.2d 811 (1972); Sauer v. Richland Township, 8 Pa. Comm. 464 (Comm. Ct. 1973); Mobil Oil Corp. v. Zoning Bd. of Adjustment, 5 Pa. Comm. 535 (Comm. Ct. 1972); Shomo v. Derry Borough, 5 Pa. Comm. 216 (Comm. Ct. 1972).

13935 Mich. App. at 217, 192 N.W.2d at 327.

140 Id. at 215-16, 192 N.W.2d at 326-27.

141 Id. at 210,192 N.W.2d at 324.

$142 I d$. at 213,192 N.W.2d at 326 .

143 For example, the provision in the Michigan constitution approving "religion, morality, and knowledge" lead to a favored status for religious institutions. Mrch. CoNsT. art. 11, § 1; 35 Mich. App. at 212, 192 N.W.2d at 325.

14435 Mich. App. at 215, 192 N.W.2d at 326, citing Detroit Edison Co. v. City of Wixom, 382 Mich. 673 (1969).

145 Id. 
bile home parks were licensed by the state and a massive housing shortage created a need for them..$^{146}$

The land bank antipresumption should operate in the same manner as the zoning antipresumption. The challenger would be required first to demonstrate a state policy favoring, for example, adequate housing. This policy could be indicated by state programs designed to provide public housing or to encourage ownership of private housing by lower and middle income families. The challenger to the disposition would then be required to prove actual exclusion of this type of housing from the land bank area.

After the challenger's prima facie case of exclusion is made, the land bank must produce evidence supporting the exclusion. It could refute the charge of exclusionary effect or present evidence supporting an affirmative case for the necessity for the exclusion. Such evidence could include, for example, planning considerations that make exclusion desirable, the availability of alternative housing, or a lack of demand for this type of housing. The court may decide that there is no exclusion, that the exclusion is reasonable, or that it is unreasonable and a remedy is required.

The antipresumption thus effectively provides for consideration of both state policies and local needs. The existence of this type of review will also encourage land bank officials to give consideration to broader state policies in making disposition decisions.

\section{Conglusion}

Land banking, although not a new technique, is increasingly being advanced as a solution to urban land use problems. The disposition of banked land is a key step in the land banking process. This comment suggests that the major problems in land disposition, misdevelopment and exclusion, can be effectively limited by judicial review. The experience gained in review of zoning actions provides several techniques for this purpose. Judicial review will also help shape the land banking process. Review of misdevelopment emphasizes the importance of planning and adherence to statutory authorization. Review of exclusionary dispositions points up the greater community of interests to which the land bank should be responsive. Both stress the importance of relating the disposition process to the goals that land banking is designed to serve.

Jay M. Feinman

146 The favored state policy need not be respecting housing, but housing is the most likely policy to arise in the land bank context. 